\title{
Evaluation of transmissivity in a fractured aquifer-the Nyanzari wellfield, Burundi
}

\author{
Sara Vassolo ${ }^{1}$ Christian Tiberghien ${ }^{1} \cdot$ Christoph Neukum $^{1} \cdot$ Désiré Baranyikwa ${ }^{2}$ Melchior Ryumeko . \\ Désiré Miburo² $\cdot$ Noël Nahimana ${ }^{3}$
}

Received: 1 July 2021 / Revised: 23 September 2021 / Accepted: 24 September 2021 / Published online: 8 December 2021

(c) The Author(s) 2021

\begin{abstract}
Due to population growth, the city of Gitega in the central part of Burundi is lacking drinking water. Therefore, the national urban water supply company decided to expand the Nyanzari wellfield by drilling additional wells.

Two additional wells were drilled to $80 \mathrm{~m}$ (F7.2) and $85 \mathrm{~m}$ (F8bis) depths. Step tests followed by 72-hours aquifer tests were performed in each well. Results indicate bilinear flow followed by linear flow and radial flow in F7.2. No reaction was observed in observation wells. Fracture-matrix transmissivity was estimated at $3 \cdot 10^{-4} \mathrm{~m}^{2} / \mathrm{s}$. In the case of F8bis, linear flow in an infinite flow fracture followed by radial flow was visible. Reaction was measured in observation wells. Transmissivity was estimated at $3.3 \cdot 10^{-3} \mathrm{~m}^{2} / \mathrm{s}$.

Both wells lie no more than $300 \mathrm{~m}$ apart, but no evidence of interference between them was depicted during the tests. It appears that two independent fracture systems prevail in the wellfield.
\end{abstract}

Keywords Fractured rocks · Burundi - Over-abstraction · Overflow spring · Groundwater monitoring

\section{Einschätzung der Transmissivität eines Kluftgrundwasserleiters - das Nyanzari-Brunnenfeld, Burundi}

\section{Zusammenfassung}

Aufgrund von starkem Bevölkerungswachstum fehlt der Stadt Gitega im Zentrum Burundis an Trinkwasser. Deswegen erweiterte das nationale städtische Wasserversorgungsunternehmen das Brunnenfeld Nyanzari mit zusätzlichen Brunnen. Zwei Brunnen wurden bis in eine Tiefe von $80 \mathrm{~m}$ (F7.2) bzw. $85 \mathrm{~m}$ (F8bis) gebohrt. Stufenpumpversuche gefolgt von 72-stündigen Langzeitpumpversuche wurden durchgeführt. Der Verlauf der Grundwasserabsenkung in F7.2 zeigt eine bilineare Strömung, die in eine radiale Strömung übergeht. In keiner der Grundwassermessstellen wurde eine Reaktion beobachtet. Es wurde eine Matrixtransmissivität von $3 \cdot 10^{-4} \mathrm{~m}^{2} / \mathrm{s}$ ermittelt. Im Brunnen F8bis wird eine lineare Strömung in einer Infinite-Flow-Kluft von einer radialen Strömung gefolgt. Es wurde eine Wasserspiegelreaktion in den Messstellen beobachtet. Die Transmissivität wurde mit $3,3 \cdot 10^{-3} \mathrm{~m}^{2} / \mathrm{s}$ abgeschätzt.

Obwohl beide Brunnen nicht mehr als $300 \mathrm{~m}$ auseinanderliegen wurden keine Hinweise auf Interferenzen festgestellt. Es wird davon ausgegangen, dass es sich um zwei unabhängige Kluftsystemen handelt.

Schlüsselwörter Kluftgestein · Burundi · Übernutzung · Überlaufsquelle · Grundwassermonitoring

Sara Vassolo

saraines.vassolo@bgr.de

1 Federal Institute for Geosciences and Natural Resources, Stilleweg 2, 30655 Hanover, Germany

2 Institut Géographique du Burundi, P.O. Box: 34, Gitega, Burundi

3 Régie de la Production et Distribution d'Eau et d'Électricité, P.O. Box: 660, Bujumbura, Burundi

\section{Introduction}

Drinking water supply in Burundi is provided by thousands of springs through local gravity systems (BRGM 2011). Due to significant population growth $(3.1 \%$ annually according to UN (2019)), demand is increasing steadily and supply by springs is reaching its limits, especially in urban areas. In the case of Gitega, the new political capital, the 
largest fraction of drinking water is supplied by groundwater extracted from the Nyanzari wellfield located south of the city in an environment characterized by crystalline basement rocks (Vassolo et al. 2019).

Hard-rock aquifers usually present two-staged aquifers depending on the degree of weathering, a shallow saprolite aquifer that maintains the original rock composition but behaves as a porous medium and a deeper saprock, which shows initial weathering and acts as a typical hard rock aquifer (Arias et al. 2016; Vassolo et al. 2019; Lachassagne et al. 2021). Extractable groundwater from saprock aquifers is often limited, although they can be locally very important (MacDonald et al. 2012). Groundwater flow is generally associated with geological features like joints, fractures, and fracture zones (Mazurek 2000; Ofterdinger et al. 2019), but the amount depends on storage in the rock body, which is seldom significant (MacDonald et al. 2012).

Crystalline basement rocks are widespread in equatorial Africa and represent an important source of groundwater for many countries (MacDonald et al. 2012). Howard and Karundu (1992) highlighted the need for assessing of the limited capacity for bedrock aquifers in Uganda to ensure adequate installation of wellfields. Maurice et al. (2019) investigated the potential of saprolite aquifers covered by younger sediments that provide additional storage to improve wellfields in Uganda and Tanzania. In West Africa, Magneto Resonance Sounding (MRS) has been used for evaluating groundwater reserves of weathered basement aquifers and thus boreholes can be sited in an appropriate manner (Vouillamoz et al. 2015). In Burundi, Bakundukize et al. (2016) investigated the potential of a weathered basement aquifer in the Bugesera region close to the boundary to Rwanda and found that hand dug well installation success is limited by the poor understanding of the aquifer. Walraevens et al. (2018) investigated the groundwater quality in the same area and concluded that the general hydrochemistry is controlled by weathering of hydrosilicates and that the presence of nitrate and sulfate is linked to anthropogenic pollution. In the Kirundo province, high uranium concentrations in groundwater have been found, which is controlled by weathering and evapotranspiration during groundwater recharge, groundwater flow, and discharge (Post et al. 2017). Vassolo et al. (2019) have investigated the hydrogeology of the Nyanzari wellfield in Gitega and proposed a two-stage aquifer model consisting of shallow saprolite and deeper saprock that explains the hydrodynamics in the area.

Due to acute water shortages in the city of Gitega, the national urban water supply company REGIDESO drilled new wells to enlarge the Nyanzari wellfield. Both wells were drilled to depths between 80 and $85 \mathrm{~m}$ and are located less than $300 \mathrm{~m}$ apart.

\section{Geography, land use, vegetation, and climate of the study area}

Gitega is located in the center of the country at an elevation of $1705 \mathrm{~m}$ above sea level (asl) on the Central Burundian Plateau, about $100 \mathrm{~km}$ to the east of Bujumbura, the former capital city. Geographically, it lies on the northwestern shoulder of the Birohe-Rugari-Songa Mountain range (1700-2000 $\mathrm{m}$ asl) that is separated by the Mutwenzi River from the Cene Mountains ( $2000 \mathrm{~m}$ asl), the major mountain massif on the Central Plateau (Fig. 1a).

According to the 2008 census, the city of Gitega had a population of 150,000 inhabitants. Key activities are agriculture-related with livestock breeding (goats, sheep, cows, and poultry), pasture, and small-scale agriculture with bananas, irish potatoes, peanuts, sweet potatos, cassava, beans, corn, and coffee as the main production (Ludgate and Tata 2015).

According to climate data from the Gitega airport station available at the Institut Géographique du Burundi (IGEBU), the region has a moderate climate with maximum and minimum annual temperatures ranging from 24.1 to $27.7^{\circ} \mathrm{C}$ and from 11.9 to $14.8^{\circ} \mathrm{C}$, respectively, for the period 1985-2013. The mean annual precipitation for the period 1964-2013 is $1178 \mathrm{~mm}$ with a distinct dry period from May to October and minimum rainfall in June, July, and August.

\section{Geology and hydrogeology}

The geology of Burundi and the Central Burundian Plateau is dominated by Mesoproterozoic rocks of the Kibara Belt, which extends SSW-NNE from southern Congo to southwest Uganda. The Kibara Belt is a sedimentary basin that subsequently experienced metamorphic deformation (Tack et al. 1994). The petrography of the Central Burundian Plateau consists mainly of metamorphic pelitic to psammitic metasediments and intrusive rocks (Claessens and Theunissen 1988). The dominant lithostratigraphic units of the study area are the tectono-metamorphic Kiryama and Vyanda complexes (Fig. 1a). The Kiryama complex occupies the largest part of the Nyanzari wellfield and is composed of undifferentiated metamorphic rocks, mainly intercalated schists and quartzitic layers. The eastern part belongs to the Vyanda complex built by an alteration of grey to red metapelites (phyllites) and layered, grey metaquartzites (Claessens and Theunissen 1988). The elevated parts of the Nyanzari catchment area consist of layered metaquartzites (Vassolo et al. 2019).

Elongated Precambrian fold-structures with NE orientation control the geological structure within the Central Burundian Plateau. The dominant lineament orientation fol- 


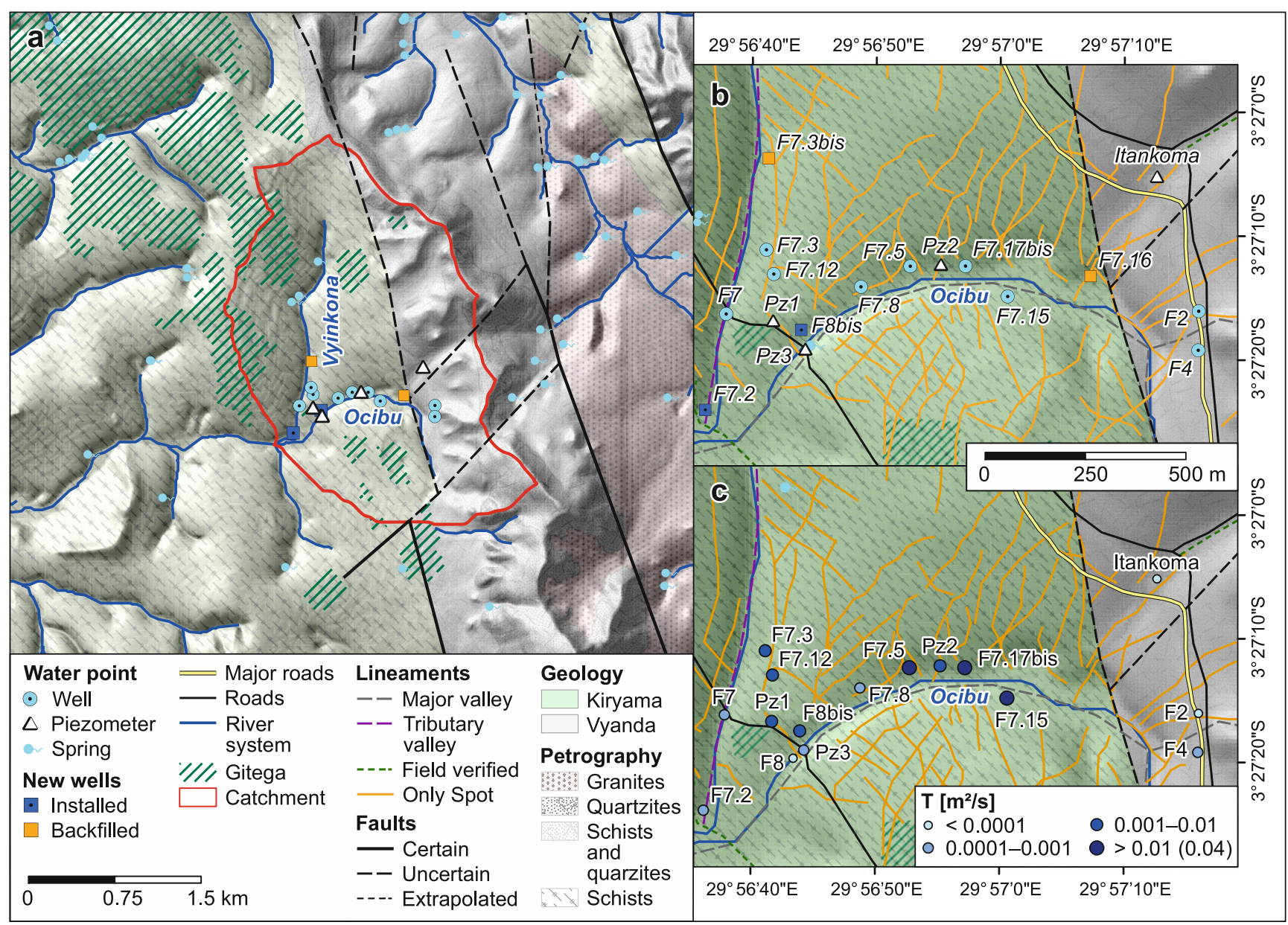

Fig. 1 a Location of the study area with $\mathbf{b}$ positions of the wells in wellfield Nyanzari and $\mathbf{c}$ matrix transmissivities

Abb. 1 a Lage des Untersuchungsgebiet mit b Positionen der Brunnen im Nyanzari-Brunnenfeld und c Matrixtransmissivität

lows the Tanganyika graben (NW) and stress release fractures developed as conjugated faults in the perpendicular direction. Dominant lineament directions in the Nyanzari catchment area are NW-SE $\left(130-170^{\circ}\right)$ and NE-SW $\left(050-060^{\circ}\right)$ (Vassolo et al. 2019). The average strike direction of the lineaments in the study area is $165^{\circ}$ (Hahne 2014). The average dipping of the structural elements (bedding, foliation) is $77^{\circ}$ (Heckmann 2016). The predominant NW-SE oriented lineaments in fissured amphibolites play a major role for groundwater flow. Weathering along these lineaments has developed heterogeneously, ranging from few decimeters to several tens of meters in thickness and plays an important role for groundwater storage. This kind of features are favored in borehole siting, as they are the most promising water-bearing structures in the area.

A detailed discussion of the conceptual hydrogeological model of the Nynazare wellfield is given in Vassolo et al. (2019). The four major hydrogeological units from top to bottom are:
- The top layer of the valleys is a ductile, clay-rich zone, which is a product of decomposed schist. The largest thicknesses are found along the axis, thinning out towards the hillslopes. Due to a high clay content, the permeability of this zone is low.

- An isovolumetric weathered schist (saprolite) layer with lower clay content, which forms the upper part of the aquifer system with medium to high hydraulic conductivity and a comparably high specific yield in unconfined areas.

- The main aquifer of the Nyanzari catchment is composed of fractured bedrock (saprock). Groundwater flow is controlled by fractures with moderate to high hydraulic conductivity and comparably low specific storage. This aquifer is semi-confined to confined.

- Fresh bedrock defines the bottom of the system. No major groundwater exchange is expected between bedrock and the aquifer system.

The catchment of the Nyanzari wellfield expands over approximately $5 \mathrm{~km}^{2}$ and includes the watersheds of the 
Table 1 Transmissivities measured in wellfield Nyanzari (Vassolo et al. 2019)

Tab. 1 Im Brunnenfeld Nyanzari gemessene Transmissivitäten (Vassolo et al. 2019)

\begin{tabular}{llll}
\hline Well & X & Y & $\begin{array}{l}\text { Transmissivity } \\
{\left[\mathrm{m}^{2} / \mathrm{s}\right]}\end{array}$ \\
\hline F7 & 29.943846 & -3.454521 & $4.47 \mathrm{E}-04$ \\
F8 & 29.945383 & -3.455496 & $1.63 \mathrm{E}-05$ \\
F7.3 & 29.944751 & -3.453082 & $6.00 \mathrm{E}-03$ \\
F7.5 & 29.947973 & -3.453452 & $4.00 \mathrm{E}-02$ \\
F7.8 & 29.946870 & -3.453910 & $3.00 \mathrm{E}-04$ \\
F7.12 & 29.944916 & -3.453626 & $2.50 \mathrm{E}-03$ \\
F7.15 & 29.950156 & -3.454128 & $4.00 \mathrm{E}-02$ \\
F7.17 (by F7.17bis) & 29.949212 & -3.453448 & $2.00 \mathrm{E}-02$ \\
Pz1 & 29.944900 & -3.454670 & $6.00 \mathrm{E}-03$ \\
Pz2 & 29.948660 & -3.453410 & $1.00 \mathrm{E}-02$ \\
Pz3 & 29.945620 & -3.455310 & $9.00 \mathrm{E}-04$ \\
F2 & 29.954435 & -3.454460 & $8.60 \mathrm{E}-05$ \\
F4 & 29.954423 & -3.455335 & $2.00 \mathrm{E}-04$ \\
Itankoma & 29.953500 & -3.451440 & $6.00 \mathrm{E}-05$ \\
\hline
\end{tabular}

Ocibu and Vyinkona streams (Fig. 1a) as well as the Bikinga plain to the south. Recharge is produced by precipitation over the whole catchment. Annual average recharge was estimated by means of the water balance equation for the period 1982-2013 at $725 \mathrm{~mm}$ (Vassolo et al. 2019). Discharge is very low (annual average of $69 \mathrm{~mm}$ for the period 1982-2013) and takes place mainly along the Ocibu and Vyikona streams (Vassolo et al. 2019).

The aquifer is assumed to be dominated by preferential flow paths along lineaments in the fractured amphibolite of the saprock. Various pumping tests performed in the Nyanzari wellfield depict the heterogeneity of the matrix in the Kiryama Formation with highest transmissivities $\left(>0.01 \mathrm{~m}^{2} / \mathrm{s}\right)$ in the center of the wellfield that decrease to values between 0.0001 and $0.001 \mathrm{~m}^{2} / \mathrm{s}$ towards the edges. The lowest transmissivity value in this formation is $0.00016 \mathrm{~m}^{2} / \mathrm{s}$ at $\mathrm{F} 8$, which has been abandoned because of low productivity (Fig. 1c, Table 1). Furthermore, evaluated transmissivities in the Vyanda Formation are, in general, lower than in the Kiryama Formation (Fig. 1c) with values between $0.00006 \mathrm{~m}^{2} / \mathrm{s}$ in Itankoma and $0.0002 \mathrm{~m}^{2} / \mathrm{s}$ in well F4.

\section{Materials and methods}

For improving groundwater supply from the Nyanzari wellfield, four new wells were drilled as close as possible to known lineament features. Nevertheless, only two of them (F7.2 and F8bis) provided enough groundwater to be used as extraction wells. Wells F7.3bis and F7.16 were not successful in terms of water supply, due to poor productivity.
After drilling completion, pumping step tests followed by aquifer tests were performed in each of the new wells. Water levels were measured using data loggers (air-pressure compensated Diver and OTT) at a frequency of $30 \mathrm{~s}$ as well as by hand with an electric contact meter. Abstraction from the wellfield was estimated hourly following the water meters of the pumped wells.

Step tests consisted of four steps of two hours pumping followed by two hours recovery each.

In the case of well F7.2, the pump was installed at a depth of $60 \mathrm{~m}$ just above the last screen section. Concerning F8bis, the pump was installed at a depth of $66 \mathrm{~m}$ just above the last screen section and extracted water was diverted to a reservoir located at the nearby pumping station.

Step test data were analysed using the software Ouaip (BRGM).

Aquifer tests consisted of a $72 \mathrm{~h}$ pumping period followed by a $72 \mathrm{~h}$ recovery period.

In the case of F7.2, pumping rate over the pumping period varied from $75 \mathrm{~m}^{3} / \mathrm{h}$ to $69 \mathrm{~m}^{3} / \mathrm{h}$. Water levels were measured in piezometers Pz1 and Pz3, in well F8bis as well as in F7.2 (see Fig. 1b for locations). For F8bis, pumping was performed at $69 \mathrm{~m}^{3} / \mathrm{h}$. Water levels were measured in piezometers Pz1 (at $73 \mathrm{~m}$ from F8bis) and Pz3 (at $48 \mathrm{~m}$ from F8bis), in well F7.2 as well as in F8bis (see Fig. 1b for locations).

The wellfield was pumped as usual and abstractions were estimated using water meters. Discharge from the Nyanzari and OCIBU springs (Fig. 1b) were measured manually with a bucket and chronometer to confirm that pumping test activities do not affect them.

Pumping rates in the tested well were measured at the outlet of the discharge pipe located $50 \mathrm{~m}$ downstream from the pumped wells. Measurements were carried out by timing the filling of a $230 \mathrm{~L}$ drum. The wells were pumped using a 6 " KSB submersible pump with a minimum pumping rate of $18.45 \mathrm{~m}^{3} / \mathrm{h}$ at a maximum depth of $19 \mathrm{~m}$, a maximum pumping rate of $61.13 \mathrm{~m}^{3} / \mathrm{h}$ at a maximum depth of $88 \mathrm{~m}$, and an average of $40 \mathrm{~m}^{3} / \mathrm{h}$ at a maximum depth of $152 \mathrm{~m}$. The raising main was a $2^{\prime \prime}$ galvanized steel pipe connected to the $3^{\prime \prime}$ outlet of the pump via a reduction.

Two groundwater samples were taken at each site, the first during the step test and the second just before switching off the pump after $72 \mathrm{~h}$ of pumping during the aquifer test. Samples were targeted for analyses of major, minor, and trace elements. They were stored at $6{ }^{\circ} \mathrm{C}$ before airfreighting them in cool boxes to the BGR laboratory in Germany for analysis. Concentrations of major and minor ions were measured using a DIONEX ICS-3000 ion chromatograph $\left(\mathrm{Cl}, \mathrm{Br}, \mathrm{F}, \mathrm{NO}_{3}, \mathrm{NO}_{2}, \mathrm{SO}_{4}\right)$; a SPECTRO ARCOS ICP-OES instrument ( $\mathrm{Na}, \mathrm{K}, \mathrm{Ca}, \mathrm{Mg}, \mathrm{P}, \mathrm{Fe}, \mathrm{Mn}$, $\mathrm{Al}, \mathrm{Si})$; and a UNICAM UV 300 photometer $\left(\mathrm{NH}_{4}, \mathrm{NO}_{2}\right.$, $\mathrm{PO}_{4}$ ). Instruments are calibrated daily using standard solu- 
tions and limits of quantitation are determined by 10-point calibration according to the DIN 32645 standard. Concentrations of $\mathrm{HCO}_{3}$ and $\mathrm{CO}_{3}$ were estimated by means of a SCHOTT Titroline Alpha Plus automatic titration system following a modified DIN 38409-H7-2 standard by evaluation of titration curve shapes for the identification and quantitation of these species. The contribution of $\mathrm{PO}_{4}$ to alkalinity was estimated from ICP-OES concentration data. The concentration of trace elements was measured using an AGILENT 7500 ICP-MS instrument. Precision is estimated based on results of daily check measurements according to the DIN ISO 11352:2013-03 standard, and accuracy from proficiency testing results and daily measurement of standard solutions.

\section{Results}

\section{Drilling, geology and hydrogeology}

Drilling of well F7.2 was carried out in a geological environment consisting mainly of amphibolites to a total depth of $80 \mathrm{~m}$. The first $10 \mathrm{~m}$ were drilled using rotary mud drilling with a $17^{\prime \prime}$ tricone crossing topsoil, clay and clayey sand (saprolite aquifer), which were then protected with steal casing. Next, drilling continued within the saprock aquifer using a $12^{\prime \prime}$ bit on a DTH hammer down to $80 \mathrm{~m}$ through different degrees of fractured amphibolites followed by fresh amphibolites and fresh granite that define the bottom of the aquifer. Important water strikes appeared at depths between 40 and $60 \mathrm{~m}$ leading to a total yield of around $50 \mathrm{~m}^{3} / \mathrm{h}$ (Fig. 2). The well was constructed using $180 / 203 \mathrm{~mm}$ diameter PVC casing and screens $(1 \mathrm{~mm}$ slot size), the latter starting at a depth of $31 \mathrm{~m}$. The interannular space was filled with gravel pack up to $10 \mathrm{~m}$ followed by clay, drilling chips, and cement for sealing in the upper $3 \mathrm{~m}$. Airlifting over $45 \mathrm{~min}$ produced varied rates from $72 \mathrm{~m}^{3} / \mathrm{h}$ to $83 \mathrm{~m}^{3} / \mathrm{h}$ at the end of development. Static groundwater level was measured at $11.77 \mathrm{~m}$ below ground level.

In well F8bis, the same amphibolite environment was drilled to a total depth of $85 \mathrm{~m}$. As for F7.2, drilling started with rotary mud drilling and a $17^{\prime \prime}$ tricone. Due to the presence of a clay layer at $4.5 \mathrm{~m}$, the drilling tool had to be replaced by a $17^{\prime \prime}$ three blades drag bit and was used down to the bottom of the layer at $22.5 \mathrm{~m}$. Thereafter, drilling continued again using the $17^{\prime \prime}$ tricone through clayish sand down to $27.4 \mathrm{~m}$. In this section, polymeric mud was added to shield the borehole walls, which became unstable due to the sandy geology and steel casing was installed to avoid borehole collapse. Drilling continued within weathered amphibolite using $12^{\prime \prime}$ bit on a DTH hammer down to $45.5 \mathrm{~m}$ and thereafter through compact to fractured plagioclase enriched amphibolite down to $65 \mathrm{~m}$. From this depth, amphi- bolite with hornblende and strongly fractured plagioclase followed. In this borehole, the first $45.5 \mathrm{~m}$ belong to the saprolite aquifer, which is underlain by the saprock aquifer. The most important water strikes were encountered between 55 and $72 \mathrm{~m}$ leading to a rate above $50 \mathrm{~m}^{3} / \mathrm{h}$ (Fig. 2). The well was constructed using 180/203 mm diameter PVC casing and screens ( $1 \mathrm{~mm}$ slot size) to a depth of $74 \mathrm{~m}$. The lower $11 \mathrm{~m}$ were backfilled by collapsed material. Screens started at $47 \mathrm{~m}$ depth. The interannular space was filled with gravel pack up to $28 \mathrm{~m}$ followed by clay, drilling chips, and cement for sealing in the upper $3 \mathrm{~m}$. Groundwater level was measured at $25.85 \mathrm{~m}$ below ground. Development with airlifting of around $90 \mathrm{~min}$ produced an average yield of $45 \mathrm{~m}^{3} / \mathrm{h}$.

The data from the new boreholes allowed improving the Nyanzari hydrogeological model. Whereas at well F8bis both saprolite and saprock aquifers are present, the saprolite aquifer at F7.2 is poorly developed and the saprock aquifer dominates (Fig. 2). This implies that the saprolite aquifer is present with variable thickness in the Nyanzari valley, but wedges out at the western edge. Groundwater is only encountered at considerable volumes within the fractured environment of the saprock, which is confined in the valley, but unconfined at the western rim. Groundwater strikes in the wells also occurred at the contact between both aquifers, but these water strikes were comparably less important (Fig. 2).

\section{Step test}

Analysis of the step test data at wells F7.2 and F8bis were difficult, due to the continuous wellfield pumping that superposed the tests. Measurement of pumping rates was not accurate, but good enough to allow interpreting the drawdown data.

Measured groundwater levels and discharges during the step test in F7.2 are presented in Fig. 3a. The first step at $75 \mathrm{~m}^{3} / \mathrm{h}$ shows anomalies in the specific drawdown line (Fig. 3b), probably due to an unstable pumping rate at that high level. Critical yield, at which linear and non-linear losses are equal, is calculated at $184 \mathrm{~m}^{3} / \mathrm{h}$. However, this value is very uncertain because the pumping rates used in the test are much lower. Analysis results indicate linear loses at $396 \mathrm{~s} / \mathrm{cm}^{2}$ and non-linear losses at $7750 \mathrm{~s}^{2} / \mathrm{m}^{5}$ (Fig. 3b). Because well loses do not limit the possible extraction rate, it can be concluded that the screens have been correctly selected and the borehole has been well constructed.

Groundwater level and discharges measured during the step test in well F8bis are presented in Fig. 3c. For this well, step test analysis (Fig. 3d) indicates a critical yield at $240 \mathrm{~m}^{3} / \mathrm{h}$, linear losses at $71.3 \mathrm{~s} / \mathrm{m}^{2}$ and non-linear at 1070 $\mathrm{s}^{2} / \mathrm{m}^{5}$. Again, critical discharge is doubtfull here because 


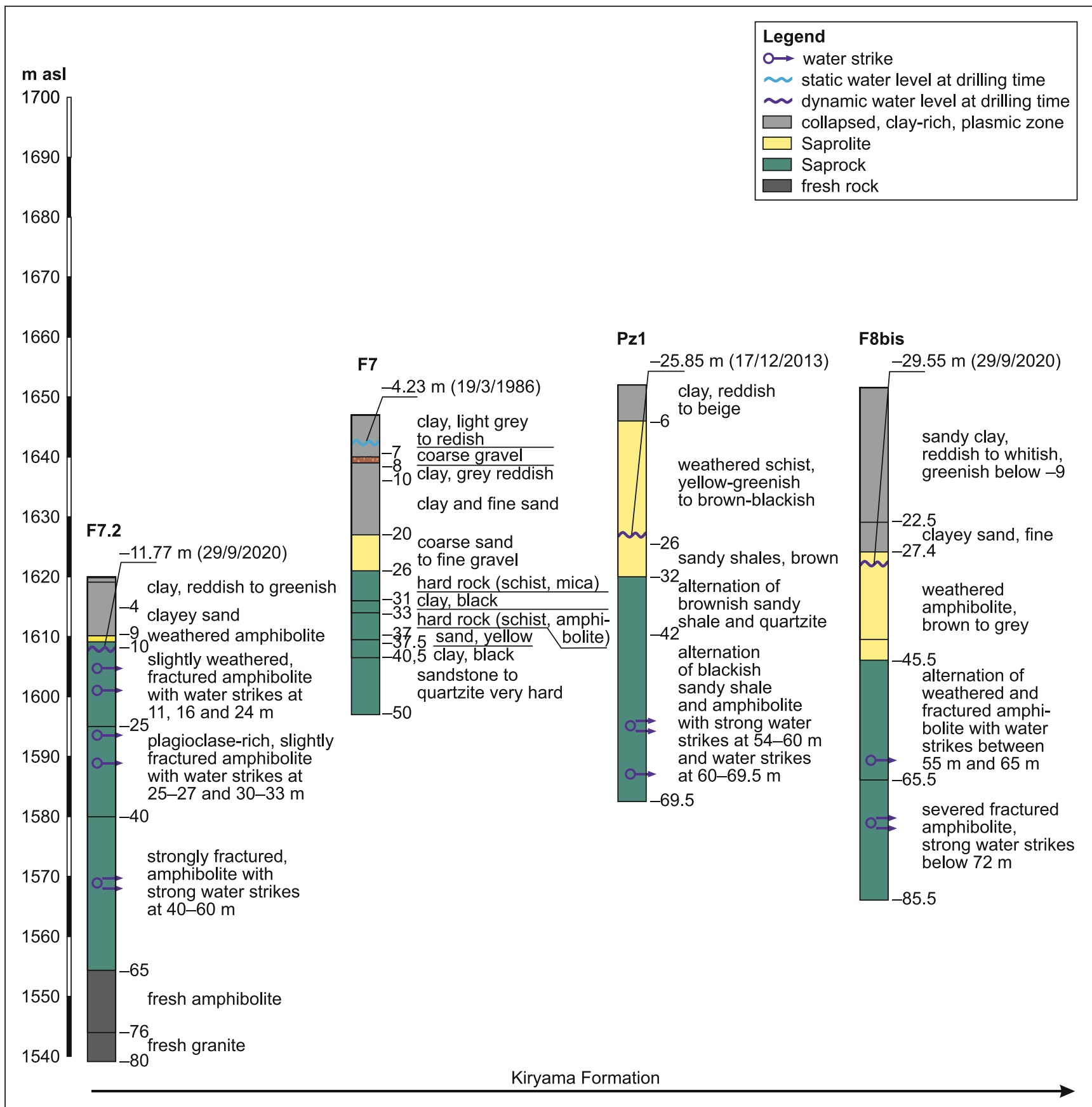

Fig. 2 Borehole stratigraphy and hydrogeology for the Nyanzari wellfield

Abb. 2 Bohrlochstratigraphie und Hydrogeologie für das Nyanzare-Brunnenfeld

the rates used during the test are much lower. The low well losses lead to the conclusion that the screens have been adequately selected and that the borehole has been well constructed.

\section{Aquifer test}

Flow during aquifer tests in fracture media traverses different phases (Horne 1997; Bardenhagen 2002): linear flow when groundwater is provided solely by the fracture, bilinear flow once the matrix starts to react, again linear flow once the fracture has been emptied, and finally radial flow. The expression of these phases in the measured drawdown depends on the fracture and matrix geometries and their hydraulic conductivities, the overall test duration, and the frequency of drawdown measurements.

Groundwater levels recorded during the aquifer test in well F7.2 show significant response to the test only in the 


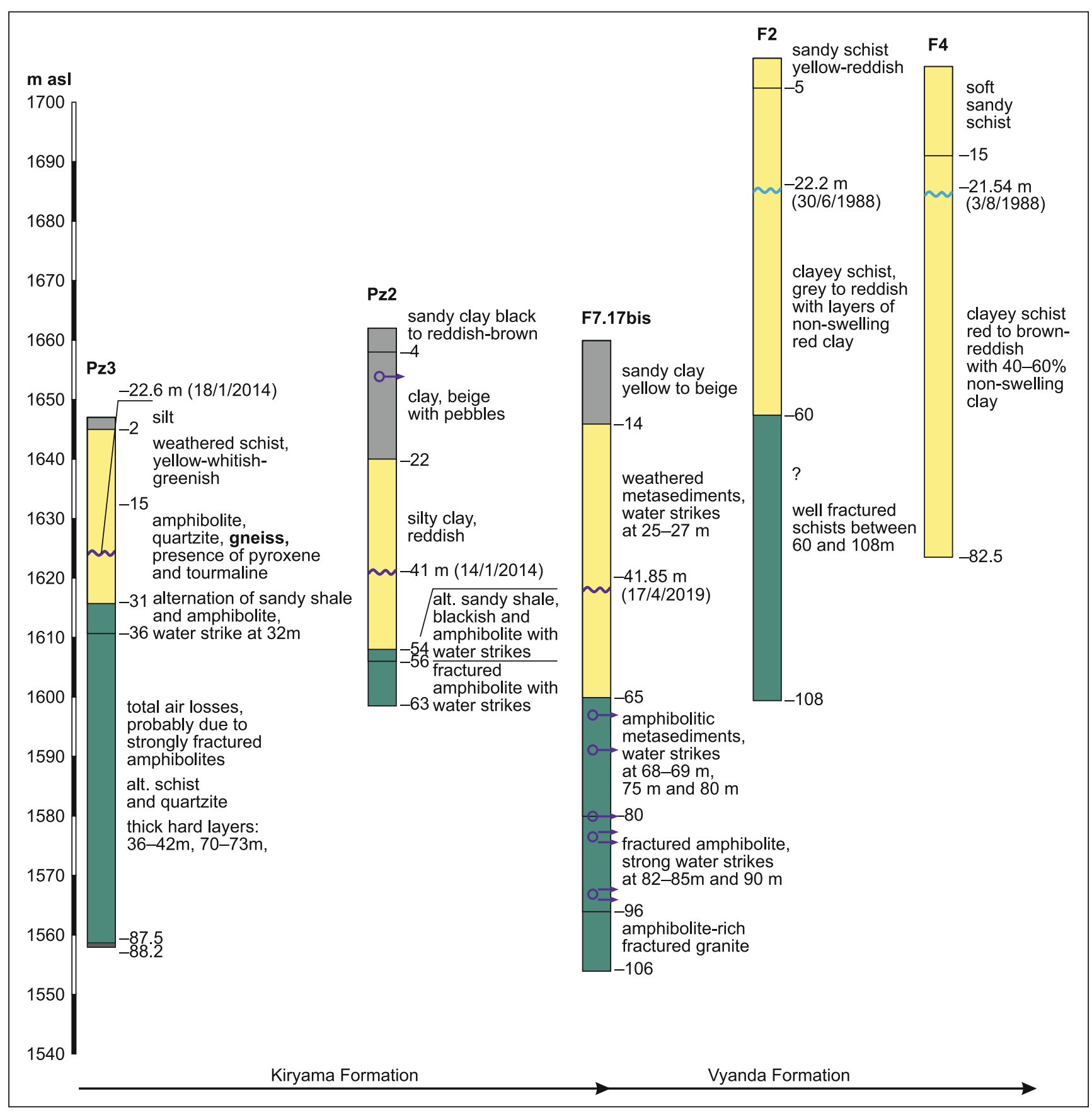

Fig. 2 (Continued)

Abb. 2 (Fortsetzung)

pumped well (Fig. 4a) and not in the observation wells. This effect can be explained by the fact that lineaments in the study area are mainly NE-SW oriented and well F7.2 intersects a different fracture system than the piezometers and well F8bis.

The drawdown curve in well F7.2 does not show the first linear flow phase. It starts with the combined bilinear flow from fracture and matrix followed by linear flow from the matrix, and finishes with radial flow (Fig. 4b). It is at this last stage of the curve that the test can be analysed by means of common methods like Theis or Jacob, which are only valid for an infinite medium with radial flow (Fig. 4c).

The test interpretation using the Theis-Jacob (1946) method results in a transmissivity of $3.1 \cdot 10^{-4} \mathrm{~m}^{2} / \mathrm{s}$ for the drawdown curve and $2.1 \cdot 10^{-4} \mathrm{~m}^{2} / \mathrm{s}$ for recovery. The difference between results is due to superposition of the wellfield pumping activities, as indicated by the continuously 
a

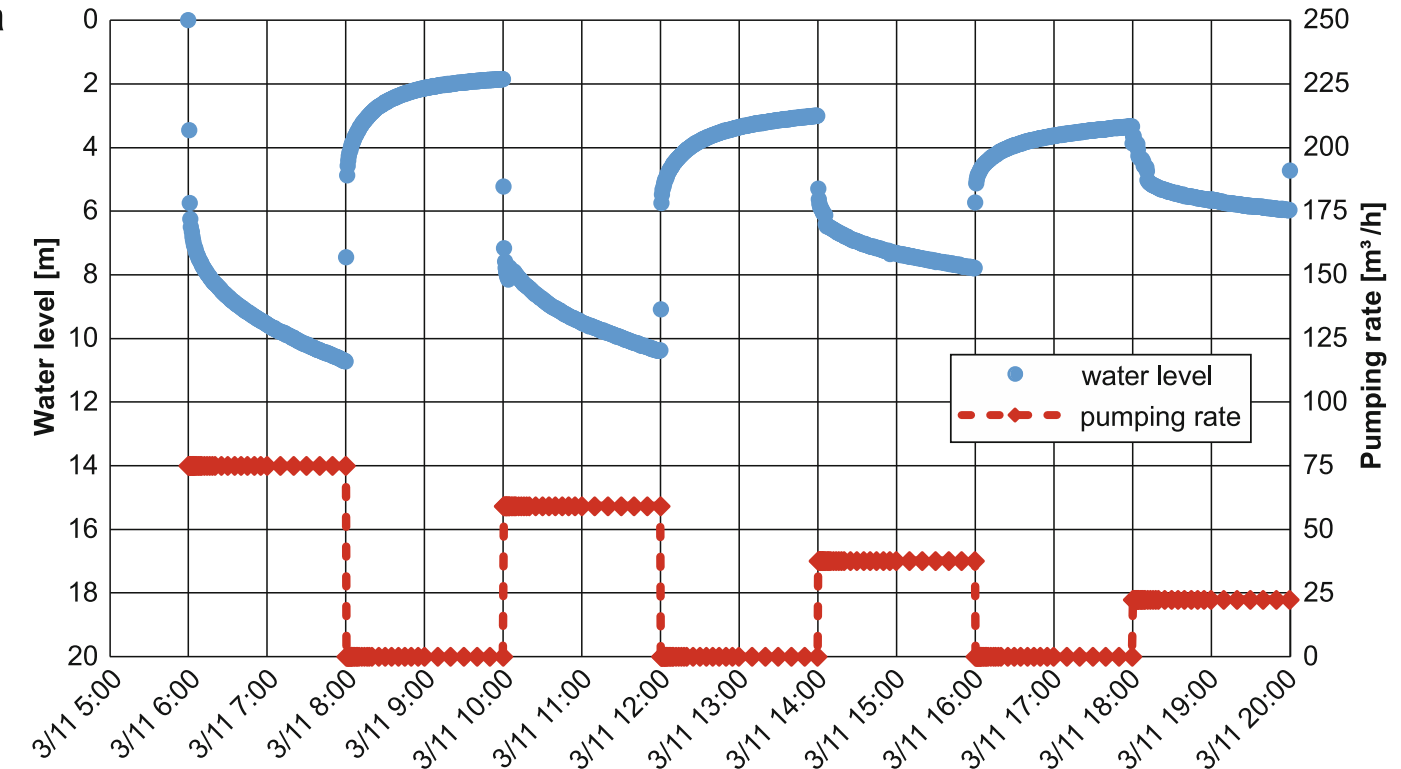

b

Characteristic curve

Pumping rate $\left[\mathrm{m}^{3} / \mathrm{h}\right]$

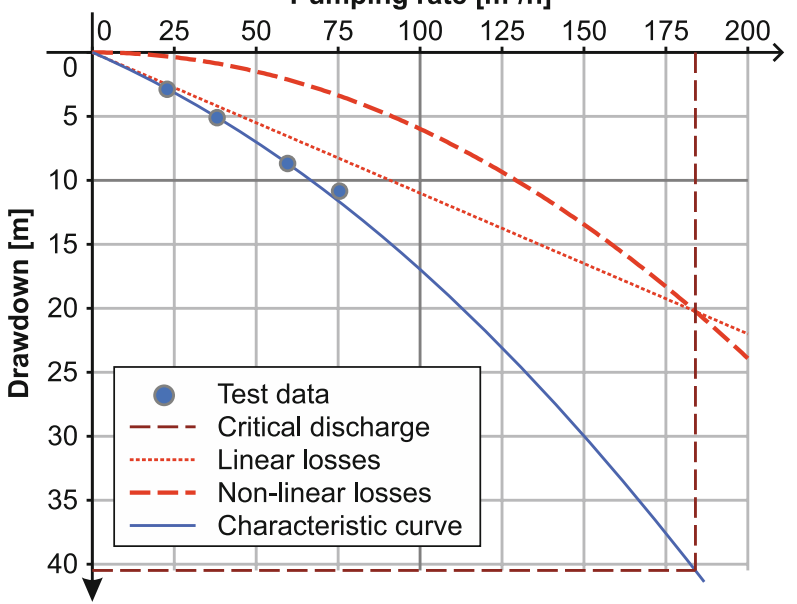

Specific drawdown line

Pumping rate $\left[\mathrm{m}^{3} / \mathrm{h}\right]$

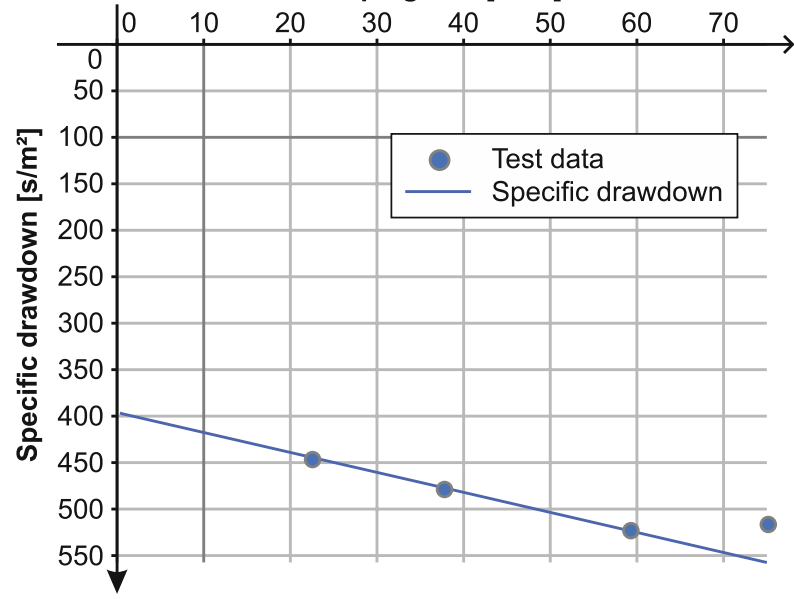

\begin{tabular}{|l|l|l|l|l|}
$\begin{array}{l}\text { Calculated } \\
\text { linear }\end{array}$ & $\begin{array}{l}\text { Calculated } \\
\text { non-linear }\end{array}$ & $\begin{array}{l}\text { Measured } \\
\text { specific }\end{array}$ & $\begin{array}{l}\text { Calculated } \\
\text { specific }\end{array}$ & $\begin{array}{l}\text { Deviation } \\
\text { (sim-obs) }\end{array}$ \\
\hline dram
\end{tabular} linear non-linear specific

drawdown drawdown drawdown [m] drawdown $[\mathrm{m}]$

$\left[\mathrm{h} / \mathrm{m}^{2}\right]$

\begin{tabular}{|c|c|c|c|c|c|c|c|c|c|}
\hline & $x^{2}$ & $x^{2}$ & & & [m] & [m] & {$\left[\mathrm{h} / \mathrm{m}^{2}\right]$} & {$\left[\mathrm{h} / \mathrm{m}^{2}\right]$} & \\
\hline Step 1 & 22.4 & 2.77 & 120 & 120 & 2.5 & 0.3 & 0.124 & 0.123 & $-6.07 \cdot 10^{-3}$ \\
\hline Step 2 & 37.63 & 4.99 & 120 & 120 & 4.1 & 0.85 & 0.133 & 0.132 & $-4.26 \cdot 10^{-3}$ \\
\hline Step 3 & 59.14 & 8.57 & 120 & 120 & 6.5 & 2.1 & 0.145 & 0.145 & $2.61 \cdot 10^{-2}$ \\
\hline Step 4 & 75 & 11.67 & 120 & 120 & 8.3 & 3.4 & 0.156 & 0.155 & $-5.76 \cdot 10^{-2}$ \\
\hline Step 5 & 75 & 10.73 & 120 & 120 & 8.3 & 3.4 & 0.143 & 0.155 & 0.882 \\
\hline
\end{tabular}

Fitting results

\begin{tabular}{|l|r|r|}
\hline Linear losses coef. (B) & $0.11 \mathrm{~h} / \mathrm{m}^{2}$ & $396 \mathrm{~s} / \mathrm{m}^{2}$ \\
\hline Non-linear losses coef. (C) & $5.98 \cdot 10^{-4} \mathrm{~h}^{2} / \mathrm{m}^{5}$ & $7750 \mathrm{~s}^{2} / \mathrm{m}^{5}$ \\
\hline Exponent $(\mathrm{n})$ & 2.00 &
\end{tabular}

Fig. 3 Step tests in F7.2 and F8bis; a Drawdown and recoveries as well as mean discharges recorded during the test in F7.2; b Step test analysis at F7.2; $\mathbf{c}$ Drawdown and recoveries as well as mean discharges recorded during the test in F8bis; $\mathbf{d}$ Step test analysis at F8bis

Abb. 3 Stufenpumpversuche in F7.2 und F8bis; a Verlauf der Grundwasserabsenkungen und -wiederanstiege sowie mittlere Pumprate während des Tests in F7.2; b Auswertung des Tests in F7.2; c Verlauf der Grundwasserabsenkungen und -wiederanstiege sowie mittlere Pumprate während des Tests in F8bis; $\mathbf{d}$ Auswertung des Tests in F8bis 


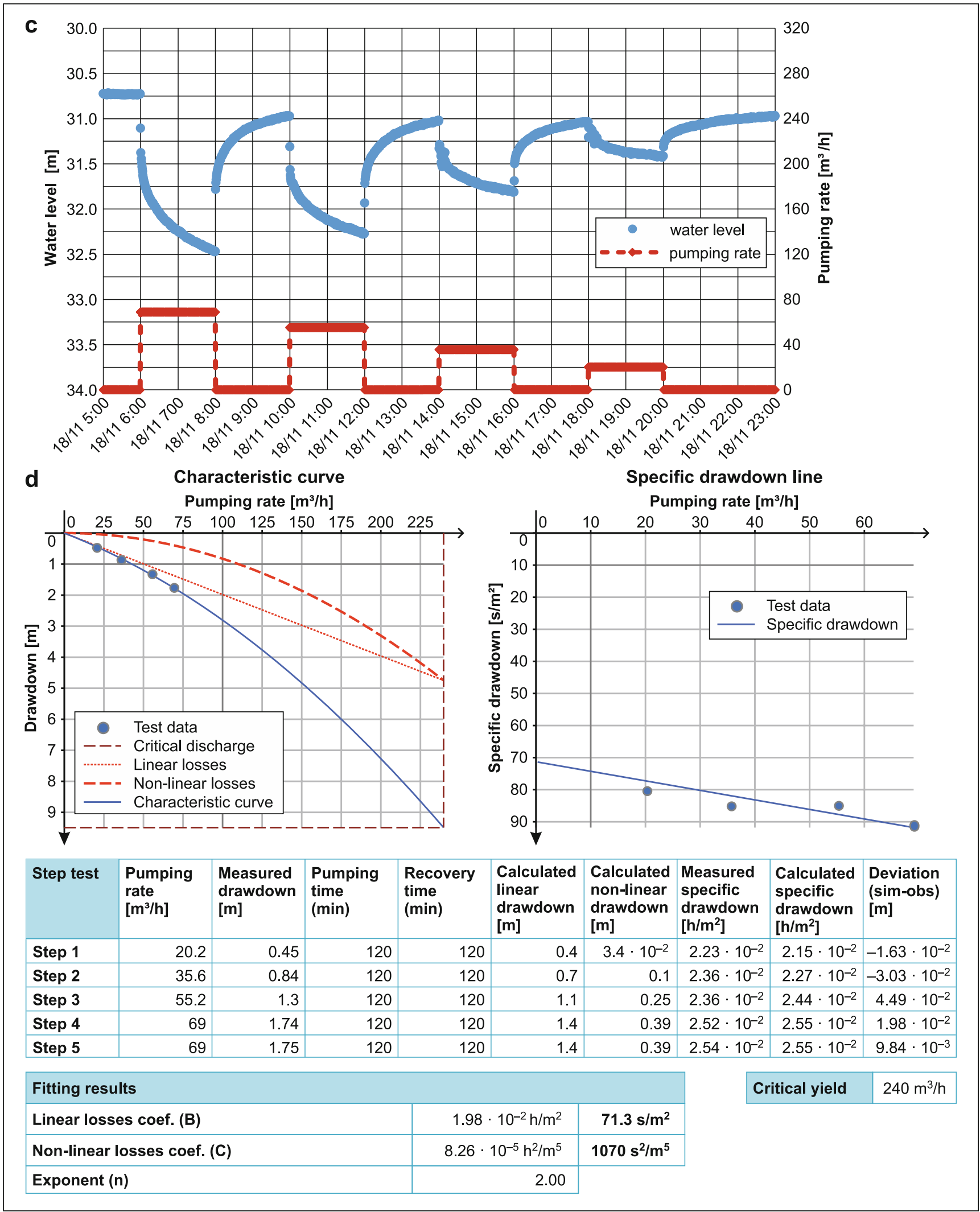

Fig. 3 (Continued)

Abb. 3 (Fortsetzung) 


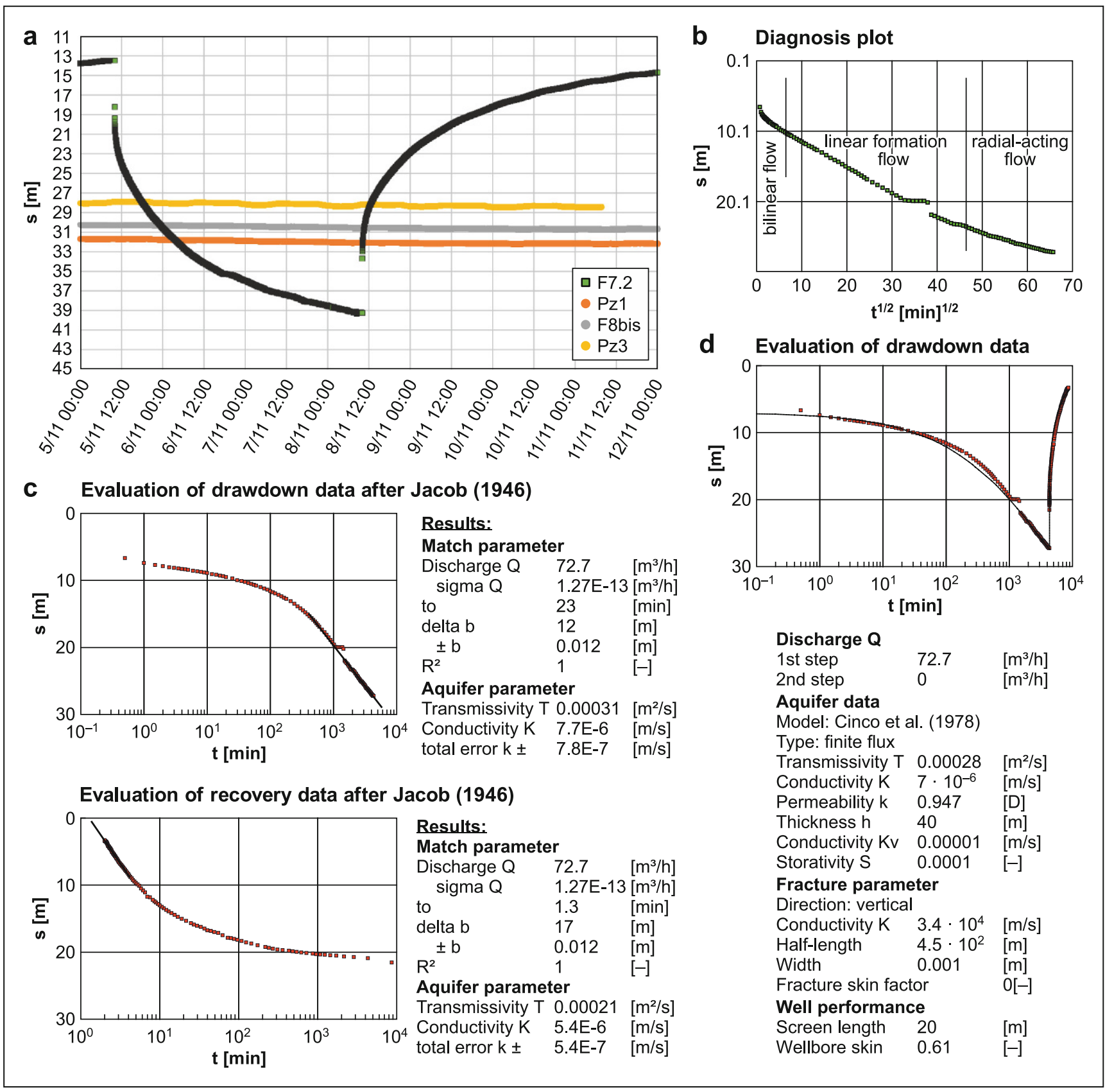

Fig. 4 Aquifer test in F7.2 ( $\mathrm{s}=$ drawdown); a Drawdown and recovery at piezometers Pz1, Pz3, F8bis, and F7.2; b Drawdown curve diagnosis with different flow phases; $\mathbf{c}$ Test interpretation (drawdown on the top and recovery on the bottom); $\mathbf{d}$ Fracture properties obtained by forward modelling of the test using Cinco-Ley et al. (1978)

Abb. 4 Langzeitpumpversuch in F7.2 (s= Absenkung); a Absenkung und Wiederanstieg in Pz1, Pz3, F8bis und F7.2; b Absenkkurvendiagnose mit verschiedenen Fließphasen; c Interpretation des Tests (Absenkung oben und Wiederanstieg unten); d Klufteigenschaften, erhalten durch Vorwärtsmodellierung des Tests mit Cinco-Ley et al. (1978)

recovering level before starting the aquifer test. Aquifer transmissivity at F7.2 is the average of both: $2.6 \cdot 10^{-4} \mathrm{~m}^{2} / \mathrm{s}$.

To estimate the fracture properties, the aquifer test was forward modelled using the Cinco-Ley et al. (1978) method, which analyses transient head data from wells intercepted by a finite conductivity vertical fracture (Fig. 4d). This fracture was probably hit at depths between 40 and $60 \mathrm{~m}$, where strong water strikes have been reported (Fig. 2). An aquifer transmissivity value of $2.8 \cdot 10^{-4} \mathrm{~m}^{2} / \mathrm{s}$ (hydraulic conductivity of $7 \cdot 10^{-6} \mathrm{~m} / \mathrm{s}$ ) was used, which is very similar to the value obtained in the test interpretation using Jacob (1946). The storage coefficient was estimated at 0.0001 , which is typical for confined aquifers. Results provide a fracture hydraulic conductivity of $3400 \mathrm{~m} / \mathrm{s}$, a half-length of $450 \mathrm{~m}$, 


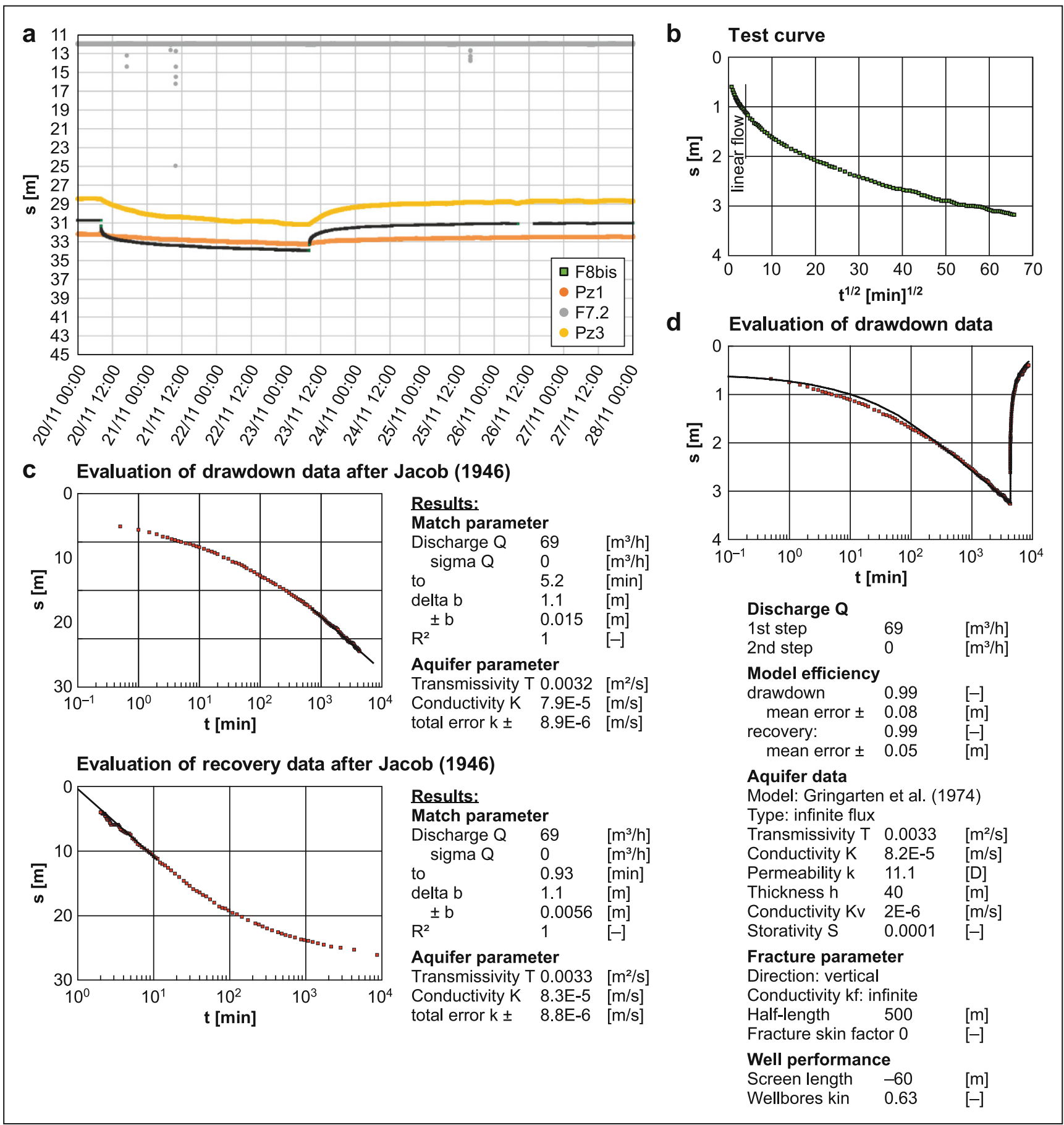

Fig. 5 Aquifer test in F8bis ( $=$ drawdown); a Water level variations at Pz1, Pz3, F7.2, and F8bis; b Drawdown curve diagnosis with different flow phases; c Test interpretation (drawdown on the top and recovery on the bottom); $\mathbf{d}$ Fracture properties obtained by forward modelling of the test using Gringarten et al. (1974)

Abb. 5 Langzeitpumpversuch in F8bis ( $\mathrm{s}=$ Absenkung); a Absenkung und Wiederanstieg in Pz1, Pz3, F7.2 und F8bis; b Absenkkurvendiagnose mit verschiedenen Fließphasen; c Interpretation des Tests (Absenkung oben und Wiederanstieg unten); $\mathbf{d}$ Klufteigenschaften, erhalten durch Vorwärtsmodellierung des Tests mit Gringarten et al. (1974) 


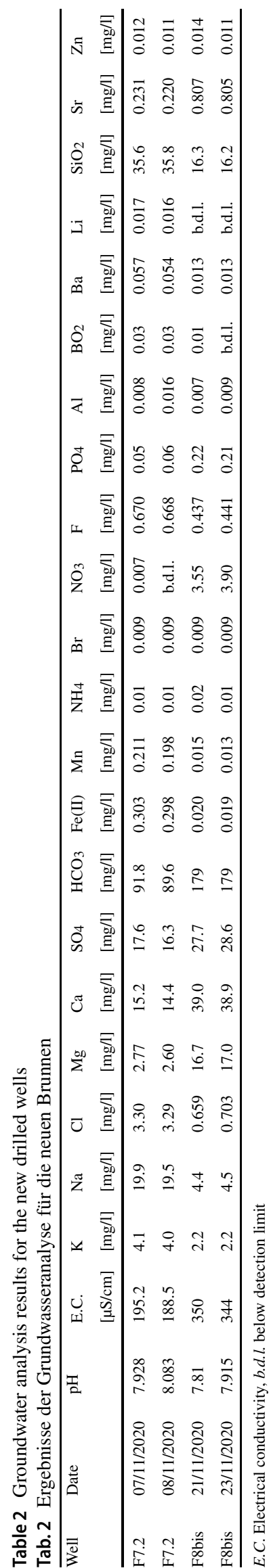

and an aperture of $0.001 \mathrm{~m}(1 \mathrm{~mm})$. Furthermore, a slight well skin effect of 0.61 was needed to be able to reproduced the measured drawdown. This low skin effect value confirms the adequacy of the borehole construction.

Groundwater level variations at well F8bis, piezometers Pz1 and Pz3, and well F7.2 were measured during the aquifer test in F8bis (Fig. 5a). In this case, besides the pumped well also the piezometers react, but no response is depicted in F7.2. This effect confirms the fact that the fracture environment were F8bis and the piezometers are located is different from the one around F7.2.

In the case of well F8bis, the drawdown measurements at the end of the pumping phase indicate radial flow, thus, this part of the test can be interpreted using Jacob (1946) (Fig. 5c). Although piezometers Pz1 and Pz3 reacted to the pumping in F8bis (Fig. 5a), unfortunatelly the test duration was too short to allow for a radial flow stage at these locations. Thus, these curves cannot be used to estimate the storage coefficient. Because of superposition of pumping activities in the wellfield, transmissivity for F8bis is estimated at $3.2 \cdot 10^{-3} \mathrm{~m}^{2} / \mathrm{s}$ with drawdown data and at $3.3 \cdot 10^{-3} \mathrm{~m}^{2} / \mathrm{s}$ with recovery data. Thus, the transmissivity of the aquifer at this location is averaged to $3.25 \cdot 10^{-3} \mathrm{~m}^{2} / \mathrm{s}$.

The drawdown curve starts with linear flow and evolves directly into radial flow (Fig. 5b), which is typical for wells drilled in an infinite flow fracture. For this reason, the Gringarten et al. (1974) method was applied for forward modelling the test data. This method has been especially developed for describing flow responses in infinite flow fractures. In order to model the measured data, a fracture with infinite hydraulic conductivity and half-length of $500 \mathrm{~m}$ (Fig. $5 \mathrm{~d}$ ), matrix transmissivity of $3.3 \cdot 10^{-3} \mathrm{~m}^{2} / \mathrm{s}$, vertical hydraulic conductivity of $2 \cdot 10^{-6} \mathrm{~m} / \mathrm{s}$, a storage coefficient of 0.0001 , and a small skin effect of 0.63 were necessary. The small value of the skin effect confirms the adequacy of the borehole construction.

\section{Groundwater quality}

Electrical conductivities of $200 \mu \mathrm{S} / \mathrm{cm}$ and $350 \mu \mathrm{S} / \mathrm{cm}$ were measured at wells F7.2 and F8bis, respectively. Groundwater $\mathrm{pH}$ is slightly alkaline with values ranging from 7.9 to 8.1 (Table 2).

Uranium concentration in groundwater is of no concern. Well F7.2 presents concentrations far below $1 \mu \mathrm{g} / \mathrm{l}$ $(0.068 \mu \mathrm{g} / \mathrm{l}$ and $0.049 \mu \mathrm{g} / \mathrm{l})$. Well F8bis has higher values $(2.28 \mu \mathrm{g} / \mathrm{l}$ and $2.39 \mu \mathrm{g} / \mathrm{l})$, but they are still far below WHO (2017) norms at $30 \mu \mathrm{g} / \mathrm{l}$.

Groundwater quality for well F8bis is similar to that of the wellfield for which cations vary following $\mathrm{Ca}>\mathrm{Mg}>$ $\mathrm{Na}+\mathrm{K}$ and anions $\mathrm{HCO}_{3}>\mathrm{SO}_{4}>\mathrm{NO}_{3}>\mathrm{Cl}$. In the case of F7.2, cations vary following $\mathrm{Na}+\mathrm{K}>\mathrm{Ca}>\mathrm{Mg}$ and anions $\left(\mathrm{HCO}_{3}>\mathrm{SO}_{4}>\mathrm{Cl}>\mathrm{NO}_{3}\right)$. 


\section{Conclusions}

The aquifer system in the Nyanzari valley is composed of an upper isovolumetric weathered schist (saprolite) layer with medium to high hydraulic conductivity and a comparably high specific yield in unconfined areas that disappears towards the western edges of the valley. The main aquifer underneath is semi-confined to confined and composed of fractured amphibolite rocks (saprock). Groundwater flow is controlled by fractures with moderate to very high hydraulic conductivity and comparably low specific storage. The bottom of the aquifer system is represented by fresh crystalline bedrock.

Aquifer tests performed in the new wells resulted in transmissivity values of $2.6 \cdot 10^{-4} \mathrm{~m}^{2} / \mathrm{s}$ for well $\mathrm{F} 7.2$ and $3.25 \cdot 10^{-3} \mathrm{~m}^{2} / \mathrm{s}$ for well F8bis, which are within the range of those measured in the past. Water quality in wells F7.2 and F8bis, although nearby, is different. Well F7.2 shows a bicarbonate-sodium-potassium water type, but F8bis a bicarbonate-calcium-magnesium type, which is the type of water encountered at the other wells in the Nyanzari wellfield. Furthermore, well F7.2 has no detectable uranium concentration, but well F8bis shows slightly elevated values. This difference is because F7.2 and F8bis extract groundwater from different fracture systems as shown by the aquifer test results.

Because piezometers react to the pumping activities in well F8bis, it can be concluded that this well is located in the same fractured environment as the rest of the wellfield located in the Kiryama Formation, which is confirmed by groundwater quality. Therefore, the wellfield should be carefully monitored during pumping of F8bis to avoid negative impacts on the other wells, including drying up with the consequent burning of the pumps.

In the case of well F7.2, piezometers did not react to the $72 \mathrm{~h}$ of pumping and groundwater quality is different. This well has been drilled in a fracture system, which is independent from those of the remaining wells in the wellfield. However, pumping interference may be possible for longer pumping times during the production of drinking water. Here again, careful wellfield monitoring is recommended.

The productivity of the wells in the Nyanzari wellfield varies significantly. While individual wells contribute very strongly to the total production, in other places the extractable water volumes are poor. The pumping tests on the wells show that the hydraulically active fractures vary considerably in terms of their effective length. The spatial orientation of the fractures, as determined by remote sensing (Vassolo et al. 2019), is also reflected in the hydraulics of the aquifer. It can be expected that the catchments of the wells are oriented approximately N-S along the fracture orientation. Major water inflow to the wells occurs within the saprock of the weathered fractured aquifer.
Acknowledgements The authors appreciate the financial support from the German Federal Ministry of Economic Cooperation and Development (BMZ), Project No. BMZ PN 416 2009.2040.5.

Funding Open Access funding enabled and organized by Projekt DEAL.

Open Access This article is licensed under a Creative Commons Attribution 4.0 International License, which permits use, sharing, adaptation, distribution and reproduction in any medium or format, as long as you give appropriate credit to the original author(s) and the source, provide a link to the Creative Commons licence, and indicate if changes were made. The images or other third party material in this article are included in the article's Creative Commons licence, unless indicated otherwise in a credit line to the material. If material is not included in the article's Creative Commons licence and your intended use is not permitted by statutory regulation or exceeds the permitted use, you will need to obtain permission directly from the copyright holder. To view a copy of this licence, visit http://creativecommons.org/licenses/by/4. $0 \%$

\section{References}

Arias, D., Pando, L., López-Fernández, C., Díaz-Díaz, L.M., RubioOrdóñez, A.: Deep weathering of granitic rocks: a case of tunnelling in NW Spain. CATENA 137, 572-580 (2016)

Bakundukize, Ch , Mtoni, E.J., Martens, K., Van Camp, M., Walraevens, K.: Poor understanding of the hydrogeological structure is a main cause of hand-dug wells failure in developing countries: a case study of a Precambrian basement aquifer in Bugesera region (Burundi). J. Afr. Earth. Sci. 121, 180-199 (2016)

Bardenhagen, I.: Aquifer test interpretation with special emphasis on the drawdown evaluation for wells within fracture networks smaller than the representative elementary volume (REV). $\mathrm{PhD}$ Thesis. University of Bloemfontein, Bloemfontein (2002)

Barrat, J.M., Mardhel, V., Gutierrez, A., Pinson, S.: BRGM: Cartes de potentialités en eau souterraine du Burundi (Burundi groundwater potential maps). ProSecEau, GTZ. (2011). in collaboration with Buscarlet, E., Lallier, S

Cinco-Ley, H., Samaniego, F., Dominguez, N.: Transient pressure behaviour for a well with a finite conductivity vertical fracture. SPE 6014. Presented at the 51st Annual Fall Technical Conference and Exhibition, New Orleans. (1978)

Claessens, W., Theunissen, K.: Carte Géologique du Burundi. Feuille Gitega, S3/29 NE. Geological map of Burundi. Sheet Gitega, S3/29 NE. Institut Géographique National, Belgique and Ministère des Travaux Publics, de l'Energie et des Mines, Bujumbura (1988)

Gringarten, A.C., Ramey, H.R., Raghavan, R.: Unsteady-state pressure distributions created by a well with a single infinite conductivity vertical fracture. SPE 4051. Presented at the SPE-AIME 47th Annual Fall Meeting, San Antonio. (1974)

Hahne, K.: Lineament mapping for the localization of high groundwater potential using remote sensing. Technical Report No. 4. IGEBU/BGR, Hannover (2014)

Heckmann, M.: Groundwater vulnerability map (COP) for the Nyanzari catchment, Gitega, Burundi. Technical Report No. 6. IGEBU, BGR, Hannover (2016)

Horne, R.N.: Modern well test analysis: a computer-aided approach. Petroway, Palo Alto (1997)

Howard, W.F., Karundu, J.: Constrains on the exploitation of basement aquifers in East Africa-water balance implications and the role of regolith. J Hydrol 139, 183-196 (1992)

Jacob, C.E.: Drawdown test to determine effective radium of artesian well. Transactions, Paper Nr. 2321. American Society of Civil Engineers, (1946) 
Lachassagne, P., Dewandel, P., Wyns, R.: Review: hydrogeology of weathered crystalline/hard-rock aquifers-guidelines for the operational survey and management of their groundwater resources. Hydrogeol J (2021). https://doi.org/10.1007/s10040-021-023397

Ludgate, N.S., Tata, J.S.: Burundi Landscape Analysis. USAID and US Government Feed the Future project "Integrating Gender and Nutrition within Extension and Advisory Services". Report (2015). https://www.agrilinks.org/sites/default/files/resource/files/ING $\% 20$ Landscape $\% 20$ Study $\% 20 \% 282016 \% 29 \% 20$ Burundi $\% 20$ \%20published\%202015_09_28.pdf. Accessed 30 Nov 2021

MacDonald, A.M., Bonsor, H.C., Dochartaigh, B.É.Ó., Taylor, R.G.: Quantitative maps of groundwater resources in Africa. Environ. Res. Lett. 7, 24009 (2012)

Maurice, L., Taylor, R.G., Tindimugaya, C., MacDonald, A.M., Johnson, P., Kaponda, A., Owor, M., Sanga, H., Bonsor, H.C., Darling, W.G., Goody, D.: Characteristics of high-intensity groundwater abstractions from weathered crystalline bedrock aquifers ion East Africa. Hydrogeol J 27, 459-474 (2019). https://doi.org/10.1007/ s10040-018-1836-9

Mazurek, M.: Geological and hydraulic properties of water-conducting features in crystalline rocks. In: Stober, I., Bucher, K. (eds.) Hydrogeology of crystalline rocks. Water science and technology library, vol. 34, Springer, Dordrecht (2000) https://doi.org/10.1007/ 978-94-017-1816-5_1

Ofterdinger, U., MacDonald, A.M., Comte, J.-C., Young, M.E.: Groundwater in fractured bedrock environments: managing catchment and subsurface resources-an introduction. Geol. Soc 479, 1-9 (2019). Especial Publications https://doi.org/10.1144/SP4792018-170

Post, V.E.A., Vassolo, S., Tiberghien, C., Baranyikwa, D., Miburo, D.: Weathering and evaporation controls on dissolved uranium concentrations in groundwater: a case study from northern Burundi.
Sci. Total Environ. 607-608, 281-293 (2017). https://doi.org/10. 1016/j.scitotenv.2017.07.006

Tack, L., Liégeois, J.P., Deblond, A., Duchesne, J.C.: Kibaran Atype granitoids and mafic rocks generated by two mantle sources in a late orogenic setting (Burundi). Precambrian Res. 68, 323-356 (1994)

UN: World Population Prospects: Prepared by the Population Division of the Department of Economic and Social Affairs of the United Nations Secretariat (2019). https://www.worldometers. info/world-population/burundi-population/, Accessed $28 \mathrm{Apr}$ 2021

Vassolo, S., Neukum, Ch , Tiberghien, Ch , Heckmann, M., Hahne, K., Baranyikwa, D.: Hydrogeology of a weathered fractured aquifer system near Gitega, Burundi. Hydrogeol J 27, 625-637 (2019). https://doi.org/10.1007/s10040-018-1877-0

Vouillamoz, J.-M., Lawson, F.M.A., Yalo, N., Descloitres, M.: Groundwater in hard rocks of Benin: regional storage and buffer capacity in the face of change. J Hydrol 520, 379-386 (2015)

Walraevens, K., Bakundukize, C., Enock Mtoni, J., Van Camp, M.: Understanding the hydrochemical evolution of groundwater in Precambrian basement aquifers: a case study of Bugesera region. J. Geochem. Explor. 188, 24-42 (2018). https://doi.org/10.1016/j. gexplo.2018.01.003

WHO (2017) Guidelines for Drinking-water Quality. Fourth edition incorporating the first addendum. ISBN 978-92-4-154995-0

Publisher's Note Springer Nature remains neutral with regard to jurisdictional claims in published maps and institutional affiliations. 